Grounds. He noted that they were closely associated, flying about together as if already paired. The two birds, which were seen within ten feet for several minutes, were more conspicuously marked than those usually seen here in the winter, and were apparently in their breeding plumage.

An extreme case of extra-limital breeding of another passerine species, the Parula Wiarbler (Parula americana), is of interest in this connection. In 1952 a male and two females with nests were discovered on the coast of California 1500 miles west of the normal range of this species. James Fisher considered this a "most fantastic example of a songbird nesting where it shouldn't." (Peterson, R. T., and J. Fisher, 1956. Wild America,
Houghton Mifflin Co., Boston). The incident is discussed at some length in a recent issue of a western bird journal (Williams, L., K. Legg and F. S. L. Williamson, 1958. Breeding of the Parula Warbler at Point Lobos, California. Condor, 60:345-354). Williams, et al, point out that this was the first record of the species west of the Rocky Mountains and the southwestern deserts. "It is believed that, other conditions being suitable, the fortuitous occurrence of individuals of both sexes in an area in which an abundance of lichens hanging from trees provided nest sites and material similar to those used in the normal breeding range of the species induced breeding in these birds." No repetition of breeding, or even of occurrence, has been recolded in the area in subsequent years.

\title{
First Saskatchewan Nest of Barred Owl
}

by Stuart Houston, Saskatoon

Exciting news took my mind at once from the $95^{\circ}$ sweltering heat on Sunday afternoon, June 4, when I received a phone call from Kelvington. Anton Waycheshen had travelled three miles by boat and twenty-one miles by car to reach a phone and report the first Saskatchewan nest of a Barred Owl. This was an emergency, and Bill Richards and I rapidly cancelled our social engagements for the evening, and twenty minutes later we were on our way to High Hill.

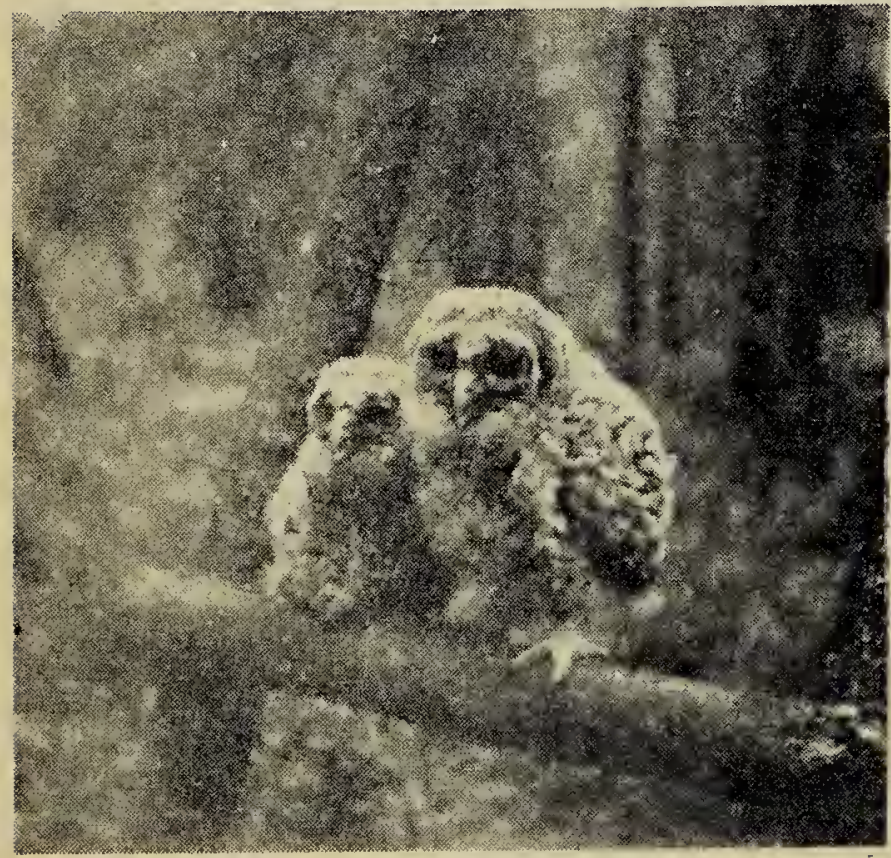

Photo by Bill Richards

Young Barred Owls, Klogei Lake, June 4, 1961.
Anton and Steve Waycheshen found the nest while fighting a forest fire in the southwest corner of the Porcupine Forest Reserve along the northeast corner of Klogei Lake (sec. 6 , twp. 39 , range 2 west of 2 nd meridian). They had seen the parent owls acting in a concerned manner in this area on Sunday, May 28, and again on May 31, when Anton climbed a spruce to inspect the only visible nest nearby, which proved to be an unoccupied crow nest. However, on June 4, Anton climbed another spruce and was able to look down on the young Barred Owls-not in the type of nest he expected, but in the upper part of a nearby black poplar stub.

Bill and I reached the Waycheshen farm at 7 p.m. and Anton and Steve took us the length of nearby Klogei Lake in their boat. On the still, cool lake we obtained relief from the oppressive heat while watching Buffleheads and White-winged Scoters.

At the end of the lake, we walked across the quarter-mile strip of recently burned mixed forest-a desolate sight-and then along the bulldozed fireguard. It was fortunate indeed that the nest was on the right side of the fire guard, for otherwise it would have been destroyed by the fire.

The Barred Owl nest was in the upper part of a black poplar stub, 18 . 
feet from the ground, where the tree had partially broken off in a previous storm. The upper part of the tree, supported by nearby spruce, had not completely broken away, but was angulated off at nearly a right angle, partially roofing the cavity of the stub which was open at one side.

The two young owls, about halfgrown and still downy, were banded. Bill Richards attempted a photograph (with fair success, considering that it was nearly 9 p.m. and that he was using kodachrome film in the deep woods without a flash attachment).

As an anticlimax, we visited a Great Horned Owl nest in a spruce about a quarter-mile distant. After I climbed up fifty feet, both young owls flew just before I reached the nest. The weaker flier of the two landed in a nearby tree. Anton climbed several trees in succession, the owl losing altitude with each flight until finally we were able to band him.

Mrs. Steve Waycheshen served us supper when we got back to the farm after dark. We were tired but very happy when we arrived back in Saskatoon at 3 a.m.

The Barred Owl was first added to the Saskatchewan list in 1959 (Houston, Blue Jay, 17:94). We have the
Waycheshens to thank for three of the six records, including the Klogei Lake bird which I banded on January 2, 1960 (Blue Jay, 18:105). This is the first nesting record for the province and it would be interesting to know whether the adult banded two winters before was one of the parents at the nest.

Russell Robertson is sure the Barred Owls occasionally nest in the Saskatchewan River lowlands near Cumberland House. Their range apparently extends south through the Porcupine Forest Reserve and, since there are records for Alberta and Manitoba, it probably occurs sparingly in the mixed forest right across the province. Support for this latter possibility is given by the comments of the Indian foreman of the firefighting crew. He came from Big River and before the Waycheshens had located the source of the strange noise, he correctly identified the strange distinctive "hoo, hoo, hoo, hoo-aw" as belonging to " a different and uncommon kind of owl." Two years ago Dr. A. E. Allin of Fort William prophesied that we would soon find a Barred Owl nest in Saskatchewan, and advised me to look in the tops of black poplar stubs. Members are advised to listen 'for the Barred Owl call, and watch for further Saskatchewan nests.

\section{BANK SWALLOWS NESTING IN GRAVEL STOCKPILE NEAR CANORA}

by Larry Morgotch, Yorkton

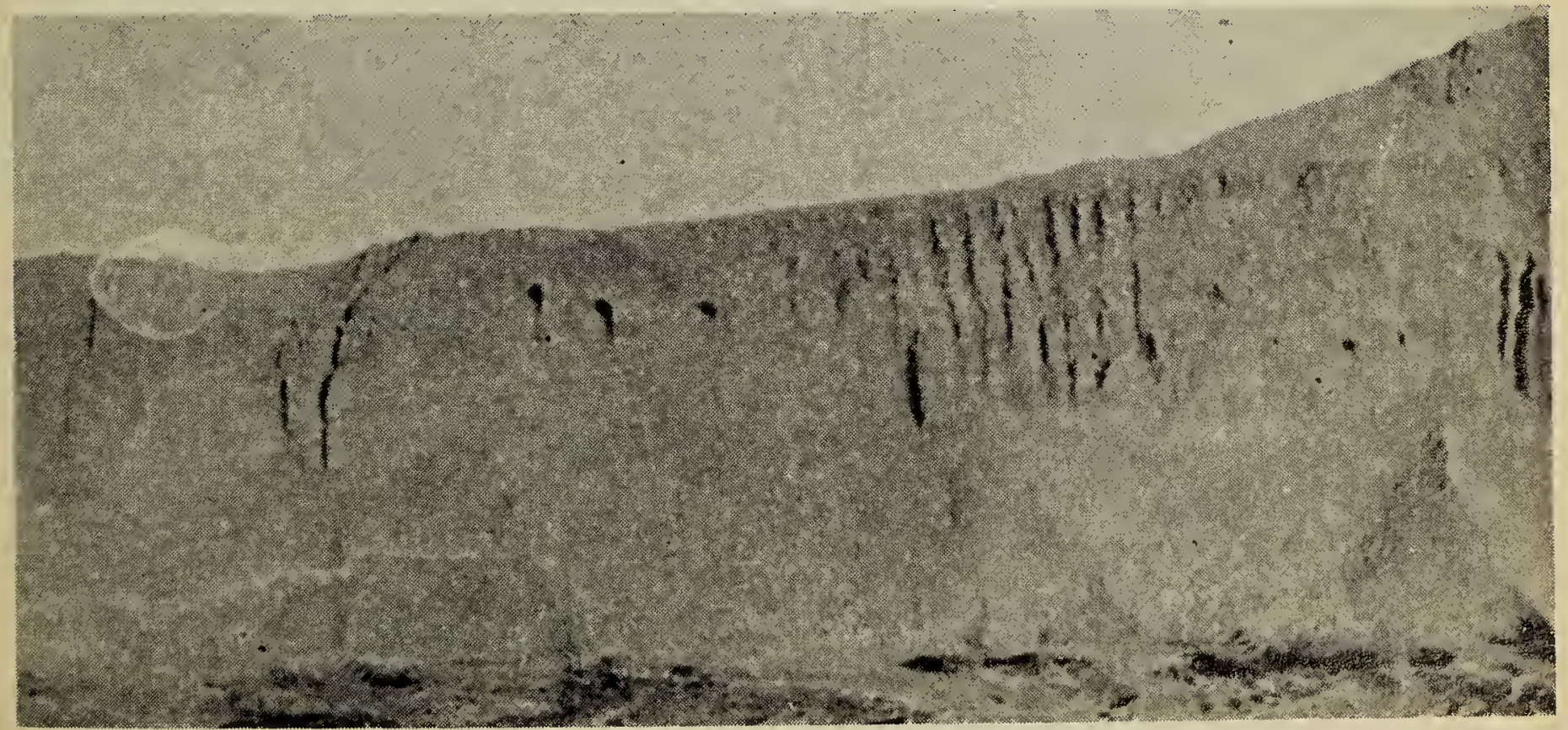

The photo show's a gravel stockpile eleven miles north of Canora, Sask. It has been undisturbed for dug without the wa'l collapsing. Bank Swallows' nests car also be found in sand dunes at Good Spirit Lake where the fine sand is well packed and tree roots help to keep it from caving in. 